\title{
The Role of Social Cohesion to Reduce Social Conflict in Tourist Destination Area
}

\author{
Suzanna Ratih Sari ${ }^{\bowtie 1}$, Nindyo Suwarno ${ }^{2}$, Windu Nuryanti², Diananta ${ }^{2}$ \\ ${ }^{1}$ Architecture Department, Diponegoro University, Semarang \\ ${ }^{2}$ Architecture Department, Gadjah Mada University, Yogyakarta
}

Permalink/DOI: http://dx.doi.org/10.15294/komunitas.v6i2.3308

Received : July 2014; Accepted: August 2014; Published: September 2014

\begin{abstract}
There are some concerns that tourism development may result in the losing of cultural identity including social cohesion of local people. This research gives different evidencees. The research found that people in Borobudur maintain their traditional value to reduce social conflict. Through direct interaction between tourists and Borobudur people, many of traditional values including social cohesion of the society are eroded. This becomes the fact that each people only tried to collect dollar from tourists as much as possible by ignoring togetherness as traditional principle of their live. This may create disharmony among the society. To eliminate this gap, people tried to tighten the relationship through re-empowering traditional social cohesion called "guyub" and "gotongroyong". It is expected that integrity and cohesiveness in a social structure could always be maintained. Along with this, satisfying and maintaining at least the traditional social cohesions of destination community is vital to reduce social conflict.
\end{abstract}

\begin{abstract}
Abstrak
Ada beberapa kekhawatiran bahwa pengembangan pariwisata dapat menyebabkan daerah tujuan wisata kehilangan identitas budaya mereka termasuk kohesi sosial masyarakat. Penelitian ini dilakukan secara kualitatif dengan menggunakan metode studi kasus. Penelitian ini menemukan bahwa masyarakat Borobudur sangat peduli terhadap nilai-nilai tradisional untuk mengatasi masalah yang dimunculkan pariwisata. Melalui interaksi langsung antara wisatawan dan masyarakat sebagai host tujuan wisata, banyak nilai-nilai tradisional termasuk guyub sebagai kohesi sosial masyarakat yang terkikis. Hal ini menjadi fakta bahwa setiap orang memikirkan diri sendiri mencoba untuk mengumpulkan dollar dari wisatawan sebanyak mungkin dengan mengabaikan kebersamaan/guyub sebagai prinsip dalam hubungan sosial mereka. Hal ini dapat membuat ketidakharmonisan di antara masyarakat. Untuk menghilangkan kesenjangan ini, orang mencoba mempererat tali silaturahmi dengan memberdayakan kembali kohesi sosial yang disebut "guyub" dan "gotong-royong". Diharapkan integritas dan kekompakan dalam struktur sosial dapat selalu dipertahankan. Seiring dengan ini, mempertahankan peran kohesi sosial tradisional dari masyarakat di daerah tujuan wisata sangat penting untuk mengurangi konflik sosial.
\end{abstract}

Keywords: tourism activities; social cohesion; social conflict

How to Cite: Sari, S.R., Suwarno, N., Nuryanti, W., \& Diananta, D. 2014. The Role of Social Cohesion to Reduce Social Conflict in Tourist Destination Area. Jurnal Komunitas: Research And Learning In Sociology And Anthropology, 6(2):294-302. doi:http://dx.doi.org/10.15294/komunitas.v6i2.3308

(C) 2014 Semarang State University. All rights reserved 
Jurnal Komunitas 6 (2) (2014): 294-302 295

\section{INTRODUCTION}

Tourism industry provides social impact especially to the host community. Social contacts between tourists and local people may result in mutual appreciation, understanding, tolerance, awareness, learning, respect, etc. Residents are educated about the outside world without leaving their homes, while their visitors significantly learn about a distinctive local culture. Local communities are benefited through contribution by tourism to the improvement of the social infrastructure like schools, libraries, health care institutions, internet cafes, and so on. Besides, if local culture is the base for attracting tourists to the region, it helps to preserve the local traditions and handicrafts which maybe were on the link of the extinction. But on the other sides, tourism has the power to affect cultural change. Successful development of a resource can lead to numerous negative impacts. Among these are overdevelopment, assimilation, social conflict, and artificial reconstruction. While presenting a culture to tourists may help preserve the culture, it can also dilute or even destroy it. The point is to promote tourism in the region so that it would both give incomes and create respect for the local tradition and culture. In such condition local people need something like social cohesion that could assist them to protect from any kinds of negative impact from tourism activities that especially lead to social conflict among the host.

\section{METHODS}

The method used in this research is descriptive method. By using this method, the researcher would describe in detail the role of social cohesion to reduce social conflict in Candirejo Borobudur. This kind of social cohesion will then lead to strengthen people relationship and bring harmony to local people. The Borobudur people are unique due to the historical story. As the most famous tourist attraction in Central Java, a lot of tourists are coming and visiting Borobudur temple. There are many factors forces local people to make any changes in their living. Therefore, this method is fit to explain all the phenomena related to that matter.
This research is basically supported by primary and secondary data. Observasion and indepth interview are executed to explore about the role of social cohesiob to reducing the occured conflict among people due to tourism activities.

\section{THEORETICAL FRAMEWORK}

According to Maxwell (1996), the definition of social cohesion is a process of building shared values and communities of interpretation, reducing disparities in wealth and income, and generally enabling people to have a sense that they are engaged in a common enterprise, facing shared challenges, and that they are members of the same community. (Maxwell J., 1996). Social cohesion usually also used by communities to tighten social relationship among the people. Social cohesion is actually one of the principle concept to create harmony of life. While, a cohesive community is one where:

1. there is a common vision and a sense of belonging for all communities;

2. the diversity of people's different backgrounds and circumstances are appreciated and positively valued;

3. those from different backgrounds have similar life opportunities; and

4. strong and positive relationships are being developed between people from different backgrounds in the workplace, in schools and within neighbourhoods (House of Commons, 2004).

As a cumulative societal concept, social cohesion is the set of positive externalities accruing from social capital, in addition to the sum of factors promoting equity in the distribution of opportunities among individuals (IABD, 2006). Social cohesion is the capacity of a society to ensure the well-being of all its members, minimising disparities and avoiding marginalisation ( Council of Europe, 2008). Social Cohesion can be further understood as one aspect of social capital. In reference to terminology from Social Network Analysis this aspect is referred to as "bonding" or "local" social capital. It is created amongst persons in small communities with frequent personal interaction. Such smaller communities are them- 
selves connected through intermediary actors (brokers) that dispose, hence, over "bridging" social capital (Putnam, 1003).

Thinking about the "overall of social cohesion", which comprises local communities and the brokers, needs to take into account both aspects of social structure. In Indonesia, the most popular social cohesion is "guyub" and "gotong royong". "Guyub" is actually one of the famous social cohesion existed almost in all Javanese villages. "Guy$u b$ " related to individual and social value. In other word, "guyub" as tolerance value is a Javanese tradition that put individual and social value in the same position without giving any disturbances toward community integrity. By doing so, integrity and cohesiveness in a social structure could always be maintained.

"Gotong royong" means more than just a gesture of helping each other toward a designated goal. "Gotong Royong" is a tradition passed down through generations that it becomes a habit, something that is innate and done even without any indication or being asked. Active participation in "gotong royong" is a "guyub" visualization. They were never ask reward from other people they helped. The spirit of local people to help each other, work together is a magnificient of "guyub". They have frequently been referred to as a tradition of the "Indonesian people." (Koentjaraningrat, 1985). In many village works, also consider "guyub" and " $g o-$ tong royong" as a practice that performs the social characteristic of Indonesian society (Karamoy, 1983).

"Guyub" and "gotong royong" as "mutual Cooperative" is an important key word in understanding social cohesion works in the community. "Guyub" is the main word of paguyuban (Gemeinschaft) actually. Gemeinschaft (paguyuban) is a form of social integration based on personal ties. Gemeinschaft is a German word, translated as 'community', used by sociologist Ferdinand Tonnies (1855-1936) to define an 'ideal type', or model, society where social bonds are personal and direct and there are strong shared values and beliefs.
Soekanto (1990), defined Gemeinschaft as paguyuban as a positive relationships among the people. According to him, paguyuban is a form of common life in which members are bound by the inner relationship which is natural, pure and eternal. The basic relationship is love and a sense of inner unity that is already predetermined, it can be found in the family, neighborhood and so forth. Principal characteristics of paguyuban are: (1) intimate, (2) private, and (3) exclusive.

Historically, Cooperative behavior among human beings has been culturally seen as a necessity. It might not be quite realistic to assume that individuals are always looking out for themselves and that they do so by weighing the costs and benefits of their behavior. Gotong royong activities can also function as collective action of group that essentially improves access to services and improves welfare outcomes of households. Those may stem from the overall relationships with others in the community that are being established in local associations, and which may well be more important than the specific function of the associations. (Andreas Diekmann, 2003)

\section{RESULTS AND DISCUSSION}

Candirejo Tourism Village is one of tourism villages exists in surrounding Borobudur Temple, Magelang, Central Java. As one of tourism villages Candirejo offered many kinds of tourism potentials physically as well as non physically. Candirejo tourism village is located in Magelang Regency, Central Java, Indonesia. This village area is closed to Borobudur Temple the biggest Buddhist Temple in Indonesia. The location is situated around $3 \mathrm{~km}$ from Borobudur Temple. Candirejo is being promoted by local government for tourism destination since 1996 and has many tourists and visitors visited each year. Candirejo is representing conventional Javanese culture and daily life through traditional houses, cultural shows, art and craft, ceremonies, farming and local 
food. Besides, pure nature and environment are added points for a tourism village. Candirejo is also completed by many supporting facilities, such as transportation, telecommunication, medical, and accommodation facilities. The accommodations in tourism village are special. Visitors can spend the nights using homes stay provided in the village. It gives visitors a memorable moment because they can feel a purely village atmosphere. Candirejo has over 50 homestays open to visitors and offers several tour packages including cooking classes featuring traditional cuisines and snacks. Spend the night in traditional houses to further blend in with the village, and join in with any of many rituals performed in Candirejo.

There are many activities offered to tourists in Candirejo tourism village. For example: exploring the village by foot or horse carriage and discovering the variety of things to see. Have a chat with the village's communities and get closer look into the culture and way of life of the people. For a break from "modern" life, tourists designate a few days to watch, learn and experience life in this quaint village, where ancient traditions are still followed, and indeed the village is best known for how it has maintained the authenticity of such traditions even there is forced of tourism existed in this village.

The most attractive issue rose in this research is since Candirejo was declared as the first tourism village and become pilot project for the other tourism village surrounding Borobudur, there are many changes had already made for fulfilling the tourists consumption. The changes made by local people mostly are the provision of tourism attractions that concerned about sustainability of local value. For examples people change the origin of natural scenic beauty, natural landscape of the village, local traditional culture, traditional way of local people's life, etc., as tourism attractions.

Local people also change some village areas for building tourism facilities. This changes had create conflict among the people. People are trying to chase dollars from tourism activities as many as possible. They are tending to neglect other people. No more "guyub/togetherness, no more friendshipness, and no more "gotong-royong". To learn more detail about this matter, therefore in this research tried to focus on how far people used "guyub" and "gotong royong" as social cohesion to eliminate social conflict due to tourism activities and used it as a strategy for preserving local value.

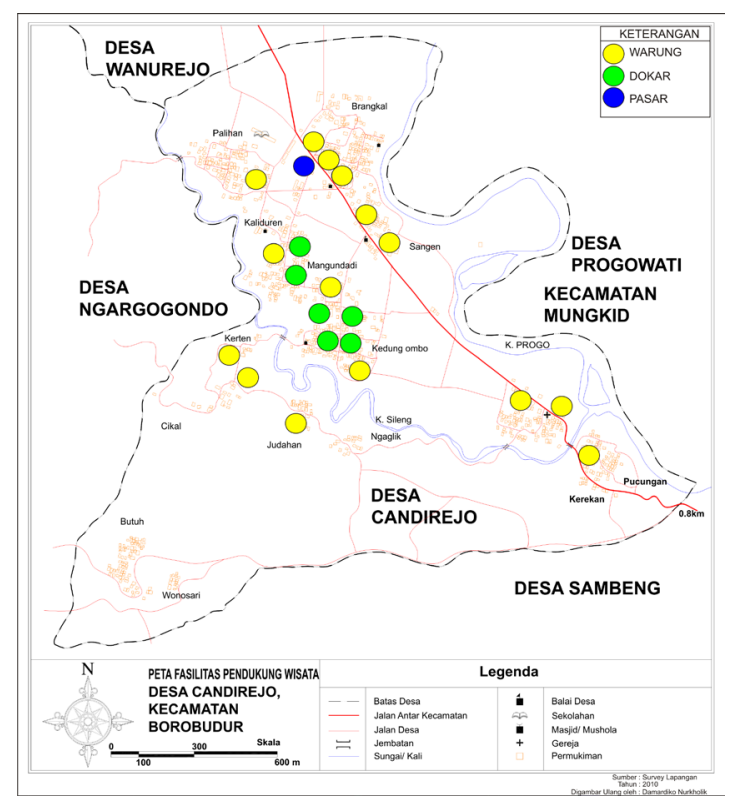

Map 1. The Map of Candirejo Village

The Role of "Guyub" and "Gotong Royong" as Social Cohesion

Based on statistical data presented by tourism village Cooperative, the number of tourists visited Candirejo reached 2500 persons per year. It was a great number compared to other tourism villages surrounding Borobudur Temple. Candirejo become the first successful tourism village program in Central Java. Eventhough, the advantage of tourism activity is not yet optimally reached by the whole local people, but it has already brought a very significant influence to local people. People have motivation for developing their life through tourism industry. Many of tourism small scale industries were established and many of tourist attractions were created. They even created their traditional houses which so called "rumah Jawa Kampung" and "rumah Jawa Limasan" to be homestay. In terms of cultural changes, there are some concerns that tourism de- 
velopment may lead to destinations losing their cultural identity by catering the perceived needs of tourists - particularly from international markets.

Tourism activity in Candirejo is actually an industry and is dominated by community. One of the purposes of tourism activities is improving living condition of the community. Therefore, if it will not well maintain, it can easily create some hindrances to achieve the objectives of tourism purpose and has a tendency to forget social and cultural impacts. Such condition will lead tourism contribute to a wide range of social problems - many of which seem insignificant but detract from the quality of life of local residents. Intrusion on daily life, loss of privacy, and a sense of crowding contribute to ill feelings towards tourism development.

The changes occurred due to instead of preserving local identity; some of communities are trying to adopt tourist culture. In this case, people also competing to get benefit from tourism activities by responding tourism in many ways. This becomes one of the reasons that many traditional values had already eroded. People are no longer respect the traditional value as their basic concept of their life. For example: local people change their own style of living. People become more modern than before. In the tourism development, they change traditional technology into modern ones. Presently, many local people ignored traditional culture. Therefore, through this direct interaction between tourists and host destination, many of traditional values including social cohesion of the society are slowly diminished. This becomes the fact that many of the fears surrounding tourism are closely associated with uncontrolled, unsustainable and massed tourism growth that could easily create social conflict as occurred in Candirejo village, one of the tourism villages in Borobudur Regency.

Before tourism project implemented in Candirejo village, local community have spirit to keep "guyub" and "gotong royong" as social cohesion in every single of village activities. Just like Borobudur community in general, Candirejo community have characteristics as Javanese people who are very traditional. In the daily life, the Candirejo people still influenced by culture and traditional beliefs. Candirejo community as rural people have a way of life which are friendly and harmonious. Helping each other, hand in hand and mutual Cooperative in every community activities. This characteristic is a reflection of Candirejo community until now.

Based on Indonesia Language Dictionary, "guyub" means social cohesion among local people. "Guyub" also means togetherness/kebersamaan. While, gotong royo$n g$ " is a kind of mutual assistance, usually between family members or neighbors in a village. This mutual assistance as Bintarto (1980) said, is always maintained and required in many aspects of life, so that mutual assistance will always be in various forms adapted to the cultural conditions of the community. The function of "guyub" and "gotong royong" as social cohesion is related to its capability in performing their roles through sharing information among the group members, reduction of opportunistic behavior, and facilitation of collective decision-making.

People made this social cohesion to be become principle of life that could tighten the relationship among them and it is not easily changed by any influences. In Candirejo, "gotong royong" actually is a tradition in working together. It is a habit incorporated in many activities such as cleaning the village, building a religious site, making markets, or even meeting a deadline for an event. As stated by village Cooperative secretary Tour Candirejo that:

Tiyang Candirejo mriki guyube taksih sae, kathah kegiatan-kegiatan desa sing dilaksanakake sesarengan. Contonipun nyadran, saparan, Merti Dusun/resik-resik dusun ugi Merti Desa/ resik-resik desa.

Candirejo people have kept "guyub/togetherness" until now, there are many village activities which done together. Such as "Nyadran", "Saparan", "Merti Dusun"/clean the sub village, and also "Merti 


\section{Desa"/clean the village}

"Gotong Royong" is a tradition passed down through generations that it becomes a habit, something that is innate and done even without any indication or being asked. By putting in "gotong royong" people in Candirejo could realize that people around them will assist to reach a certain target including tourism activities. These kind of activities guaranteed continuity of social cohesiveness. As Mr. Slt (ex-local leader) said about the characteristic of Candirejo people that support tourism activity in their village:

Pada saat saya menjabat sebagai aparat desa, saya berusaha untuk memperkenalkan pariwisata kepada masyarakat saya. Karena saya tahu sifat masyarakat Candirejo yang dinamis, guyub, punya keinginan untuk maju, kondusif dengan pimpinan mereka, dan patuh setelah diberi penjelasan, serta inovatif, maka memudahkan saya untuk menyusun program atau kegiatan yang mengarah pada pariwisata. Masyarakat banyak yang memberikan dukungan dan berperan aktif untuk mengembangkan kegiatan pariwisata di Desa Candirejo

At the time when I served as a public service officers village, I tried to introduce tourism to my community. Because I know the characteristc of Candirejo people which are dynamic, friendly, have desire to move forward, conducive to their leaders, and obeying after having been given an explanation, and innovative. This make me easier to set up tourism programs or activities. Many people gave support and active role to develop tourism activity in the Candirejo village.

Candirejo community even preserve their social cohesion "guyub and gotong royong" to become one of the most tourist attractions in their area as seen in the following pictures:

Such kind of relationship also happened in Purbalingga where Chinese Society hand in hand tried to preserve Chinese culture, especially the tradition of Cap Go Meh. Before the establishment of the Chine-

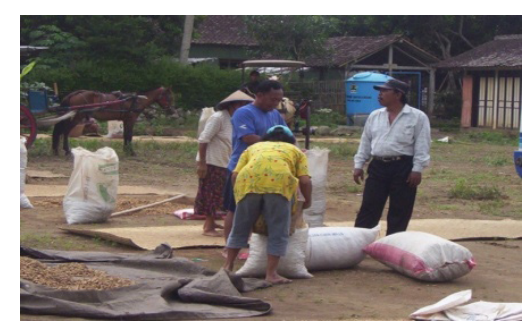

Figure 1. Harvesting Activities

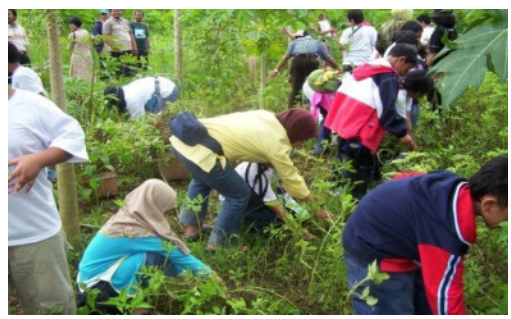

Figure 2. Village Cleaning Activity

se Society of Purbalingga, Cap Go Meh was celebrated only in the sphere of family and home, but after the Chinese Society of Purbalingga was established, the tradition was celebrated openly even to tourist so that not only the Chinese but also people of Purbalingga can feel its presence. (Fitriyani, 2012)

Presently, everything has slowly eroded. People are starting neglecting "guyub" in their daily life. They just chase a piece of big cake for their own and they never think about other people. Each people only tried to collect dollar from tourists as much as possible. They access tourists directly without concerning other people and sell any kinds of tourism assets (potential land for tourism development) through direct selling or person to person. They are also competing in providing tourism facilities such as homestay, tourist guide, travel agent, etc. Such condition further cause social gap/ disharmony among local people. The other problems rose regarding to this matter are due to each people have their own perception, need, mission, expectation towards tourism. Each people are expecting optimal benefit from tourism activities and do not want to share tourism profit with other people. People who have good access to tourists will be exist, but as for poor people who could not access tourist directly, they do not get the fruits of tourism activities. Then we must say this tourism business is only for a 
certain class of the people. This condition will further effect community participation in supporting tourism activities.

Fortunately, the local leader of Candirejo tourism village has taken promptly action to reduce this social conflict. However, if the social conflict develops in intimate relationships, the separation (between conflict realistic and non-realistic) would be more difficult to maintain. As Coser (1964) said that, the closer the relationship, the greater sense of compassion that has been embedded, so that the greater the tendency to suppress rather than express hostility. Being on secondary relationships, such as with business associates, hostility can be relatively freely expressed. This does not always happen in the primary relationships in which the total involvement of the participants make sense of such disclosure is a danger to the relationship. If the conflict is really beyond the limit, causing an explosion that jeopardize the relationship. Therefore, the local leader together with the Candirejo society developed "Koperasi Desa Wisata Candirejo"/Candirejo Tourism Village Cooperative as tourism village manager as seen in Scheme 1. It tried to manage and accommodate all the ideas of tourism development and tried to make economic concept that could provide tourism profit to Candirejo people as a whole and not individually. The existance of "Koperasi Desa Wisata Candirejo“/Candirejo Tourism Village Cooperative is to tighten the relationship among the people. As their principle of life before that they have their living spirit to always hand in hand (gotong-royong concept) and bringing forward togetherness (guyub concept). Tourism Village Cooperative tried to invite all the local people who concern toward tourism development and sit together to discuss how to create tourism activities that could give optimal economic benefit to them.

They create and make some tourism packages of local culture and nature togetherly to become tourists attraction. They also desided that they will promote local handicrafts, local agriculture system, homestays, traditional culinary, traditional dance and another potential tourists attractions existed in their village which could be offered to tourists as tourism package as well as to attract foreigners to visit together.

Figure 3 shown that there is strong relationship between tourists and local people. Tourists involve in cooking together competition held by local people as one of tourism package programmes done by Tourism Village Cooperative. In this occasion tourists learn from local people how to cook

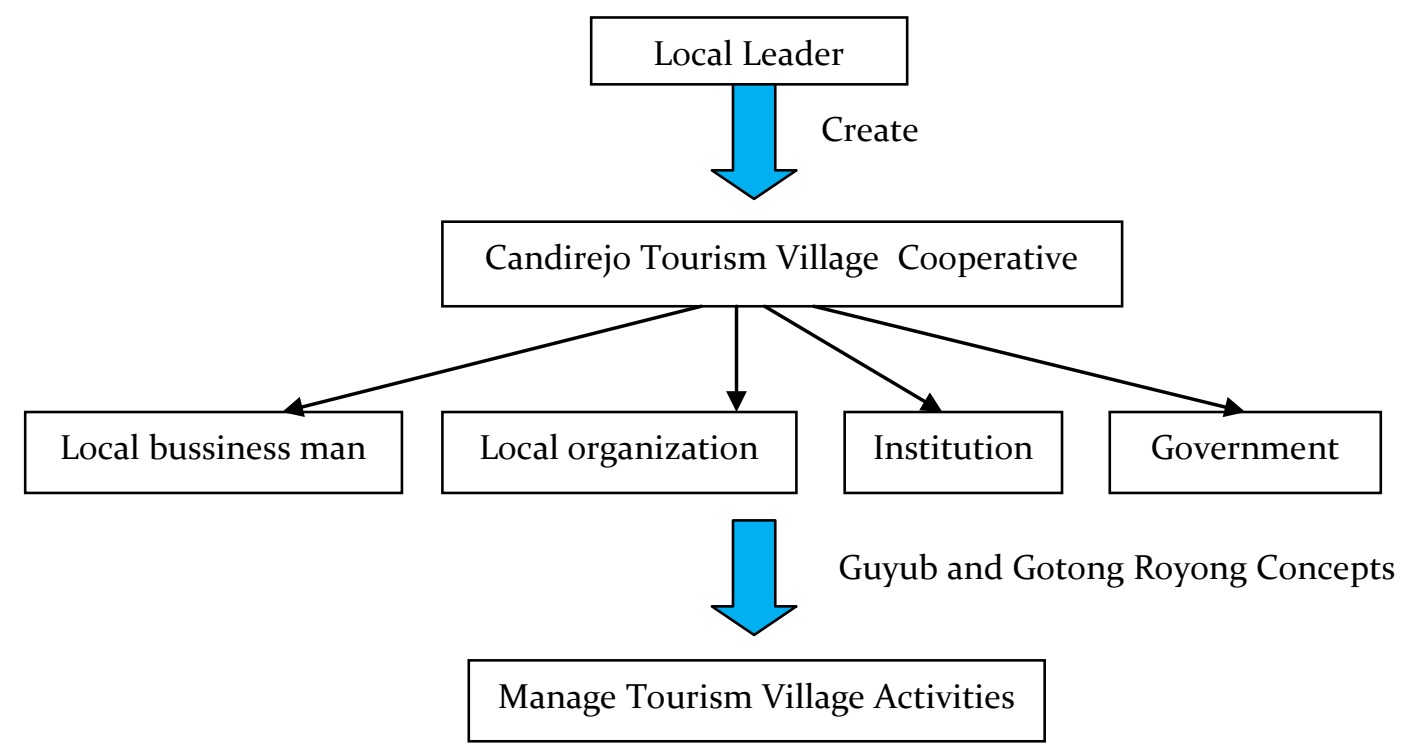

Scheme 1. Candirejo Tourism Cooperative Design 
traditional foods and then joint the competition. This activities encourage people to always keep "guyub"/togetherness.

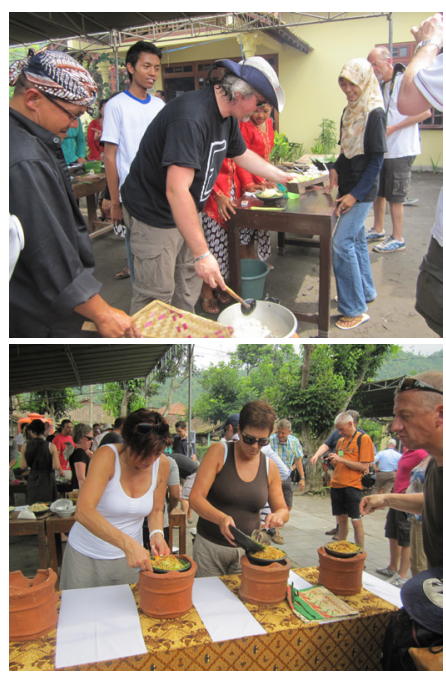

Figure 3. Cooking together tourists and local people

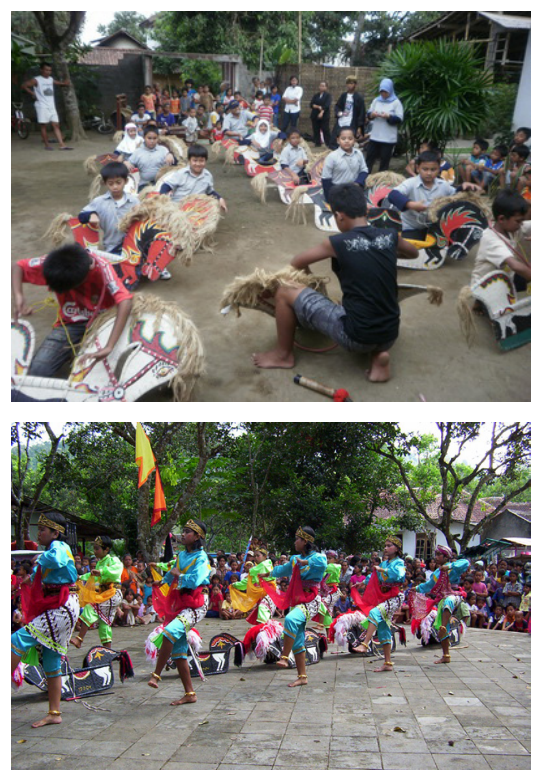

Figure 4. Tourists and local people excercised Traditional Dancing together

In figure 4 shown how people work together and hand in hand to held traditional performance in order to satisfied tourists especially international tourists. In the hand of Tourism Village Cooperative, people were organized to give optimal performance to entertain tourists. Candirejo Tourism Village Cooperative manage the tourism industries as their own entreprises that could bring a lot of fruits to all of local people.

Local leader has believe that social conflict, if managed properly, can also be an effective tool in coping with and responding to tourism and can be an agent for peace by helping develop a supportive environment. Tourism is not only about the transaction of services, but also about the interactions between humans. So, the social condition of local community is important in keeping the harmony among people.

\section{CONCLUSION}

Research on social cohesion is specified clearly the impact of tourism activities that are affecting the social condition and individuals attitudes and behaviors in Candirejo tourism village. People are involving in some social conflicts and traditional value degradation. Through "Koperasi Desa Wisata Candirejo"/ Candirejo Tourism Village Cooperative that based on "guyub and gotong royong" concept, Candirejo local people could minimize the conflict among the people. In this Cooperative, it has been proved that "guyub and gotong royong" is actually good strategy for reducing social conflict. People are becoming realize that "guyub and gotong royong" as life principle could not be left in performing living in harmony of the people. In togetherness and always hand in hand, Candirejo people could increase their economic income through tourism activities. Therefore, the multiplier effect of tourism activities traced down to every level of local people.

\section{REFERENCES}

Bintarto, R. 1980. Gotong-Royong : Suatu Karakteristik Bangsa Indonesia. Surabaya : PT. Bina Ilmu

Council of Europe. 2008. Report of the High Level Task Force on Social Cohesion in the 21st century.

Coser, L. 1964. The Functions of Social Conflict: An Examination of the Concept of Social Conflict and Its Use in Empirical Sociological Research, New York: The Free Press

Diekmann A, Preisendörfer P. G. and greenback 2003. The behavioral effects of environmental attitudes in low-cost and high-cost situations. Rationality and Society.

Fitriyani, R. 2012. Peranan Paguyuban Tionghoa Purbalingga Dalam Pelestarian Tradisi Cap Go Mehperanan Paguyuban Tionghoa Purbalingga Dalam Pelestarian Tradisi Cap Go Meh, 
302 Suzanna Ratih Sari et al., The Role of Social Cohesion to Reduce Social Conflict in Tourist

Jurnal Komunitas, 4(2).

House of Commons. 2004. available at: http://www. publications.parliament.uk/pa/cm200304/ cmselect/cmodpm/45/45.pdf

IABD. 2006. Social cohesion in Latin America and the Caribbean - Analysis, action and coordination. Washington D.C.

Karamoy, A, Gillan D and Attashendartini H. 1983. Community Based Delivery of Social Services in Indonesia: Case Study in Kampung Kebon Kosong. Jakarta: International Development Research Centre in Cooperativeeration with The Institute for Social and Economic Research, Education and Information.

Koentjaraningrat. 1985. Kebudayaan, Mentalitas, dan Pembangunan.Jakarta: Gramedia.
Maxwell, J. 1996. Social dimensions of economic growth. Eric John Hanson Memorial Lecture Series. University of Alberta.

Putnam, R. 1993. Making Democracy Work: Civic Institutions in Modern Italy. Princeton University Press:Princeton.

Ritzen. 200o. "Social Cohesion, Public Policy, and Economic Growth: Implications for OECD countries", available at:http://www.oecd.org/ dataoecd/25/2/1825690.pdf

Soekanto, S. 1982. Teori Sosiologi. Suatu Pengantar. Jakarta: PT Raja Grafindo Persada.

Tonnies, F. 1887. Gemeinschaft and Gesellschaft: A sociological view of the decay of modern society. Leipzig: Fues's Verlag. 